\title{
Role of Matricellular Proteins in Cardiac Allograft Fibrosis
}

\author{
Nadine Frerker*, Monika Kasprzycka*, Bjørg Mikalsen, \\ Pål Dag Line, Helge Scott and Guttorm Haraldsen \\ Dept. and Inst. Of Pathology, Dept of Surgery, \\ Oslo University Hospital and University of Oslo, Oslo, \\ Norway
}

\section{Introduction}

While acute rejection of solid organ allografts has become a rare clinical condition, longterm graft survival is threatened by the development of fibrosis. Such fibrosis is seen in two forms in the heart, one being an accelerated process of atherosclerosis termed transplant vasculopathy, the second a parenchymal response to the ensuing ischemia, low-grade cellular or humoral allorejection, as well as other factors.

The transplant vasculopathy (TV) of cardiac allografts (also known as graft vascular disease, chronic allograft vasculopathy or graft vascular sclerosis) is defined as a diffuse proliferative process that causes obstruction of the coronary vasculature, impairment of vascular flow and secondary myocardial ischemic injury (Mitchell, 2009). Whereas atherosclerosis of nontransplanted hearts mainly affects the proximal part of the coronary arteries, TV affects the arteries down to the level of small intramyocardial branches. Moreover, similar but less extensive changes have been observed in coronary veins (Mitchell, 2009), whereas changes in capillary basement membrane structure, as seen in chronic kidney rejection biopsies, have not been identified as a feature of chronic rejections in hearts.

The TV lesion consists of concentric intimal thickening that contains modified smooth muscle cells that have most likely migrated from the media, macrophages that contain intracellular lipids, collagen and glycosoaminoglycans (Winters \& Schoen, 2001). Cholesterol clefts in a band-like distribution and lesions resembling typical atheromatous plaques may arise in the advanced form of the disease. The endothelium and internal elastic lamina are nearly always intact. The vascular media may have normal thickness or may be thinned. Cellular infiltrates, including T-lymphocytes, both $\mathrm{CD} 4+$ and $\mathrm{CD} 8+$, and macrophages are frequently present as a superficial band in the subendothelium and deeper within the intima and media.

On the other hand, interstitial fibrosis is also a feature of transplanted hearts, partly a consequence of the ischemia associated with TV, but also total ischemic time, rejection episodes and donor cause of death. Despite these different origins of graft fibrosis, the fibrosis lesion (including intimafibrosis in TV) appears to have the occurrence of myofibroblasts or myofibroblast-like cells in common. Myofibroblasts are contractile cells 
thought to partly derive from fibroblasts and to share characteristics with smooth muscle cells, including expression of a-smooth muscle actin (SMA). They play an important role in physiologic wound healing by synthesizing collagens and exerting strong contraction forces to minimize wound areas (comprehensive reviews of myofibroblast origins, differentiation and functions can be found in (Hinz, 2010; Wipff \& Hinz, 2009). Their recruitment is thought to be mediated by cellular damage, the release of inflammatory mediators including TLR agonists (Wynn, 2008).

\section{Matricellular proteins - between cell and matrix}

The ECM consists of a complex network of structural proteins (collagens, elastin), multidomain adhesive glycoproteins (fibronectin, vitronectin, and laminin), glycosaminoglycans (GAGs) such as hyaluronan and proteoglycans (versican, syndecans, glypicans, perlecan), as well as the matricellular proteins that we shall focus on in this chapter.

Although the main role of ECM is to act as a structural scaffold for tissue and a compression buffer when tissues are subjected to stress, its ability to also provide the contextual information responsible for controlling cellular behaviour has been increasingly recognized in recent years. The biophysical properties of the matrix can regulate cellular mechanosensory pathways - through global substrate rigidity or extracellular tension. Specific domains and motifs embedded in the ECM proteins act as ligands for cellular receptors, such as integrins and discoidin domain tyrosine kinase receptors. In addition, the ECM also sequesters and hence acts as a reservoir for a wide range of growth factors and cytokines (for reviews see Cox \& Erler, 2011; Hynes, 2009; Rhodes \& Simons, 2007; Schultz \& Wysocki, 2009).

Matricellular protein is a term originally proposed by Bornstein (Bornstein, 1995) to describe secreted extracellular matrix proteins that function more as regulators of cell-matrix interactions than as structural proteins. The group of matricellular proteins includes amongst others thrombospondins, tenascins, osteopontin, periostin, osteonectin or CCN proteins. A common property of matricellular proteins is their high expression level during embryogenesis, which is strongly reduced after birth and becomes low to absent in adult life (although there are organ specific differences). Their expression re-appears at high levels in response to tissue injury (Bornstein \& Sage, 2002).

\subsection{Osteopontin}

Osteopontin (also known as $44 \mathrm{kDa}$ bone phosphoprotein, sialoprotein I, secreted phosphoprotein I, uropontin, and early $\mathrm{T}$ lymphocyte activation-1) is a multifunctional protein thought to play a significant role in a variety of biological processes, including bone resorption, immune cell activation, atherosclerosis and ECM remodeling (Scatena et al., 2007). It belongs to the small integrin binding ligand N-linked glycoprotein (SIBLING) family-related proteins. It is composed of 314 amino acid residues and is subject to profound posttranslational modifications such as phosphorylation and glycosylation (Waller et al., 2010). Osteopontin has several molecular domains of established or putative function (see Firgure), among them several integrin binding domains: an arginine-glycine-aspartic acid (RGD) cell binding sequence interacts with integrins $\operatorname{av} \beta 3, \operatorname{av} \beta 1, \operatorname{av} \beta 5$ and $a 8 \beta 1$, a serine- 

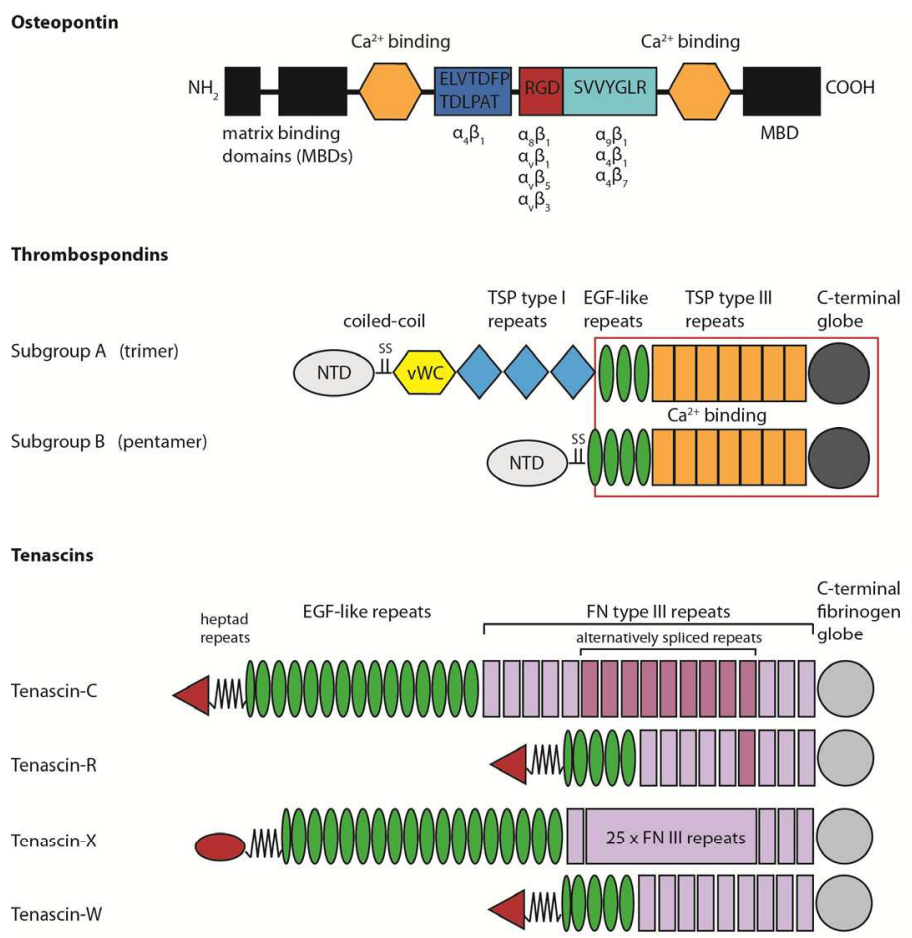

Osteonectin/SPARC

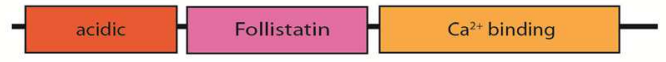

Periostin

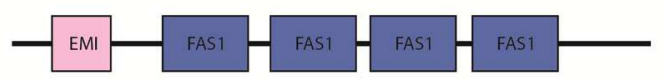

CNN proteins

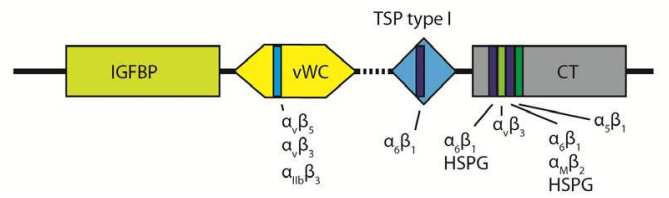

Fig. 1. Structural models of matricellular proteins.

Osteopontin: $\mathrm{MBD}=$ matrix binding domain, the integrin binding specificity is indicated below corresponding domains; Thrombospondins: NTD $=\mathrm{N}$-terminal domain, $\mathrm{vWC}=$ von Willebrand factor type $\mathrm{C}$ domain, TSP $=$ thrombospondin, red box indicates conserved domains, Tenascins: in red $=\mathrm{N}$-terminal oligomerisation domain, FN = fibronectin; Osteonectin with the three characteristic domains of SPARC-like proteins; Periostin: FAS1 domain = fasciclin-like domain 1; CCN proteins:; IGFBP = insulin-like growth factor binding protein homology domain, $\mathrm{CT}=\mathrm{C}$-terminal domain, $\mathrm{HSPG}=$ heparan sulfate proteoglycan, integrin and HSPG binding sites are indicated in colored bars, dashed line indicates the hinge region (adapted from publications Adams \& Lawler, 2004; Brekken \& Sage, 2000; C. C. Chen \& Lau, 2009; Chiquet-Ehrismann \& Chiquet, 2003; Conway \& Molkentin, 2008; Lund et al., 2009; Scatena et al., 2007). 
valine-valine-tyrosine- glutamate-leucine-arginine (SVVYGLR)-containing domain that interacts with integrins $\alpha 9 \beta 1$, a4 41 and $\alpha 4 \beta 7$ and a ELVTDFPTDLPAT domain is also reported to bind to a $4 \beta 1$ (Waller et al., 2010). Several cell types have the capacity to synthesize osteopontin, including bone cells, macrophages, endothelial cells, smooth muscle cells and fibroblasts (Schellings et al., 2004). In healthy adult organs osteopontin expression is low except for the kidney, bone, and in epithelial linings of several tissues (Schellings et al., 2004). By contrast, osteopontin expression is upregulated in pathological conditions, such as atherosclerosis (Giachelli et al., 1993) and ischemic injury (Ellison et al., 1998) including myocardial infarction (MI) (Tamura et al., 2003).

\subsection{Thrombospondins}

The known vertebrate thrombospondins fall into two subgroups, termed A (thrombospondin1 and -2 ) and $\mathrm{B}$ (thrombospondin-3, -5 , and -5/COMP) according to their oligomerization status. Hence, members of subgroup A form homotrimers and members of subgroup B homopentamers. Each thrombospondin contains multiple domains and a coiled-coil oligomerisation region (Figure). The hallmark of all thrombospondins is the presence in the carboxy-terminal half of each polypeptide of a variable number of EGF-like domains that are contiguous with seven so-called thrombospondin type 3 repeats and a C-terminal region of globular character (Adams \& Lawler, 2004).

The most well described members of the family are thrombospondin-1 and -2. Important functions of thrombospondin- 1 are activation of the TGF- $\beta$ (transforming growth factor- $\beta$, see below), inhibition of angiogenesis and de-adhesion of cells. The anti-angiogenic effect of thrombospondin-1 is caused mostly by induction of apoptosis and inhibition of endothelial cell migration (Nor et al., 2000). Thrombospondin-1 also induces de-adhesion, defined as transition to an earlier stage of adhesion process (Greenwood \& Murphy-Ullrich, 1998), in a variety of cells, by stimulating loss of focal adhesions and actin stress fibers (Greenwood \& Murphy-Ullrich, 1998; Murphy-Ullrich \& Hook, 1989). Likewise, thrombospondin-2 has been shown also to inhibit angiogenesis and cause de-adhesion by inhibiting focal adhesion in endothelial cells (Murphy-Ullrich et al., 1993, for review see Schellings et al., 2004).

\subsection{Tenascins}

The tenascin family includes: tenascin-C, $-R,-X,-Y$ and $-W$. They are all built from a common set of structural motifs: heptad repeats, EGF-like repeats, fibronectin type III repeats and a fibrinogen globe domain (FBG, see Figure). At the N-terminus each tenascin has an oligomerisation domain that in the case of tenascin- $\mathrm{C}$ and $-\mathrm{W}$ leads to the formation of hexamers while tenascin-R has been isolated as a trimeric molecule (Racanelli et al., 1992).

Tenascin- $C$ expression is very low after birth and in the normal adult heart its expression is limited to the chorda tendinae of papillary muscles (Sato \& Shimada, 2001). However, the protein reappears under pathological conditions, such as infection, vascular hypertension, myocardial infarction and experimental autoimmune myocarditis (Imanaka-Yoshida et al., 2001; Imanaka-Yoshida et al., 2002). Tenascin-C has adhesive and de-adhesive properties, depending on ECM composition and cell surface receptor binding. De-adhesion facilitates cell migration and tissue remodeling during wound healing. In contrast to tenascin- $\mathrm{C}$, tenascin-X expression remains high after birth (Geffrotin et al., 1995) and has been shown to 
mediate cell adhesion but not spreading (Elefteriou et al., 1999) Moreover, tenascin-X modulates collagen fibrillogenesis and is therefore described in more detail below.

\subsection{Osteonectin/SPARC}

Osteonectin (also known as SPARC (Secreted Protein Acidic and Rich in Cysteine) or BM40 ) is a $32-\mathrm{kDa}$ glycoprotein characterized by three modular domains (Figure): (1) an Nterminal acidic and low-affinity calcium-binding domain; (2) a disulfide-bonded, copperbinding follistatin domain (homologous to the TGF $\beta$-inhibitors activin and inhibin), and (3) the C-terminal extracellular calcium-binding domain (Clark et al., 1997; Schellings et al., 2004).

Tissue expression of osteonectin in healthy adult organs is very low except in epithelia that exhibit high turnover rates (gut, skin, and glandular tissue) (Sage et al., 1989). However, like the preceding matricellular proteins, osteonectin expression re-appears in lesions of injury such as myocardial infarction (Komatsubara et al., 2003). Osteonectin has been reported to bind to thrombospondin-1, vitronectin, entactin, fibrillar collagens and collagen type IV (Schellings et al., 2004). Additionally, it inhibits endothelial cell adhesion and proliferation (Rosenblatt et al., 1997). The de-adhesive effect is mediated through a tyrosine phosphorylation-dependent pathway, whereas its antiproliferative function is dependent, in part, on signal transduction via a G protein-coupled receptor (Motamed \& Sage, 1998). Absence of osteonectin in mice during embryogenesis resulted in pups with curly tails and reduced tensile strength of the skin. Smaller collagen fibrils that were more uniform in diameter were seen at the ultrastructural level (Schellings et al., 2004).

\subsection{Periostin}

Periostin (osteoblast specific factor-2, OSF-2) (reviewed in refs. Conway \& Molkentin, 2008; Norris et al., 2009) has a molecular weight of $\sim 90 \mathrm{kDa}$ and consists of), four-coiled fasciclinlike repeats, an aminoterminal cysteine-rich region (EMI domain), and heparin binding domains present in the carboxyl tail (Figure). In the heart, periostin is expressed at the very early stages of embryogenesis; however, it is not detected in the normal adult myocardium, except in the valves (Kruzynska-Frejtag et al., 2001; Norris et al., 2007).

Periostin can directly interact with other ECM proteins such as fibronectin, tenascin-C, collagen I, collagen $\mathrm{V}$, and heparin and serve as a ligand for integrins av $\beta 3$, av $\beta 5$ and $\alpha 4 \beta 6$. Recently, it was demonstrated that periostin plays a crucial role in activation of fibroblasts and smooth muscle cells (SMC) through FAK-integrin signaling (Li et al., 2010; Shimazaki et al., 2008). It also promotes collagen fibril formation (Maruhashi et al., 2010; Norris et al., 2007) and incorporation of tenascin-C, organizing a meshwork architecture of the ECM (Kii et al., 2010).

\subsection{CCN protein family}

$\mathrm{CCN}$ (an acronym formed from names of first three members) proteins family (reviewed in Chen \& Lau, 2009; Kular et al., 2011) includes 6 members: CYR61 (cysteine-rich 61; CCN1), CTGF (connective tissue growth factor; CCN2), NOV (nephroblastoma over-expressed; CCN3), CCN4 (WISP1), CCN5 (WISP2), and CCN6 (WISP3). All members share a 
multimodular structure, with an N-terminal secretory signal sequence followed by four conserved domains with homology to insulin-like growth factor binding proteins (IGFBPs), von Willebrand factor type $C$ repeat (VWC), thrombospondin type I repeat (TSP) and a carboxyterminal domain (CT) containing a cystein knot (with the exception of CCN5, see figure). A multimodular structure of the $\mathrm{CCN}$ proteins allows them to bind and interact with a broad range of partners including integrins, heparan sulfate proteoglycans (HSPGs), ECM components such as fibronectin and fibulin 1C, receptors like Notch1, TrkA, lowdensity lipoprotein receptor-related proteins (LRPs), growth factors including BMPs, TGF- $\beta$ and VEGF, as well as gap junction protein connexin 43. CCN proteins regulate cellular functions such as adhesion, migration, proliferation, differentiation, survival, apoptosis or extracellular matrix remodelling in a cell-type specific manner and they play crucial roles in vascular and skeletal development, angiogenesis, wound healing, fibrosis, vascular disease or cancer.

\section{Matricellular proteins in action}

\subsection{Matricellular proteins in solid organ transplantation}

Data on matricellular protein expression and function in the cardiac allografts is limited (Franz et al., 2010; Mikalsen et al., 2010; Zhao et al., 2001) but justifies further investigation. For example, TV has been associated with elevated levels of thrombospondin-1 (Zhao et al., 2001) and of tenascin-C (Franz et al., 2010). Moreover, the tenet of endothelial cell activation being at the epicentre of TV pathogenesis leads to the logic that we need a focussed understanding of how this cell type responds without the confounding noise generated from other cell types. Initial studies in our lab were therefore founded on the purification of endothelial cells from heterotopic cardiac grafts in the rat during rejection (Mikalsen et al., 2010). Grafts were fully mismatched (DA to Lewis), leading to a full rejection and loss of graft function at day 5-6, and were compared to isografts (Lewis to Lewis) to discriminate allogenicity from the surgical procedure. The extent of this analysis is a transcriptome-wide, Affymetrix-based profile of rejection on day 2, 3 and 4 and a corresponding profile of the isograft. Among the most interesting features of these profiles was, first, the observation that tenascin- $\mathrm{C}$ and periostin were the most strongly induced transcripts and, second, that the majority of transcriptional changes were similar between the allo- and isografts. These data are publicly available at the NCBI GeneExpression Omnibus (GSE16695).

Another observation of relevance is that cyclosporine and tacrolimus have been shown to induce osteopontin mRNA expression in renal tissues in vitro and in vivo (Khanna, 2005). Cyclosporine has been reported to induce upregulation of osteopontin by tubular epithelial cells resulting in macrophage infiltration and fibrosis in a rat model of chronic cyclosporine nephropathy. Whether these findings have an impact on cardiac allografts is uncertain. It appears that cyclosporine does not promote clinical TV (Gamba, Mammana, Fiocchi, Iamele, \& Mamprin, 2000; Rickenbacher et al., 1996), despite a large amount of experimental data suggesting a profibrotic effect, including enhanced production of TGF- $\beta$.

In addition, Sawada and coworkers studied the role of tenascin-C during abdominal aortato-carotid artery interposition grafting in mice (Fischer, 2007; Sawada et al., 2007). When aortas derived from tenasin-C-deficient mice were grafted to carotid arteries of tenascin-Cdeficient recipients, neointimal hyperplasia and VSMC proliferation was significantly 
reduced compared with WT-to-WT grafting. Furthermore, even if only the graft or the recipient was tenascin-C-deficient, dramatic reductions of neointimal hyperplasia occurred.

\subsection{Matricellular proteins in ischemic injury}

Given that data on matricellular protein expression and function in cardiac allograft fibrosis is currently very limited, it is interesting to look at the role of these proteins in cardiac healing and remodeling after experimental MI. Interestingly, lack of several matricellular proteins reveals remarkable phenotypes in this context (for review see Matsui et al., 2010), most of them (with the exception of thrombospondin-1) showing signs of reduced repair and resulting ventricular dilation.

Thus, osteopontin-deficient mice show significantly stronger ventricular dilation, reduced collagen synthesis and deposition in both infarcted and non-infarcted regions compared to wild-type (WT) mice (Trueblood et al., 2001). Moreover, expression and activity of MMP-2 and MMP-9 is significantly higher in the non-infarct LV in mice lacking osteopontin 3 days post-MI. The increased MMP-2 activity in the KO group persisted over the next 14 days suggesting that osteopontin modulates MMP expression and activity in the heart post-MI, thereby playing an important role in regulation of collagen deposition and fibrosis. While MMP inhibition improved heart function in both WT and KO mice, this improvement was significantly higher in mice lacking osteopontin (Krishnamurthy et al., 2009). Thus, it appears that increased osteopontin expression protects the heart from ventricular dilation and is required to maintain the structure and function of the heart after ischemic injury.

Moreover, thrombospondin-1-deficient mice exhibit severe inflammation and expansion of the ischemic lesion, as well as enhanced ventricular dilatation (Frangogiannis et al., 2005), whereas thrombospondin-2-deficient mice developed cardiac failure in response to angiotensin II infusion, followed by fatal cardiac rupture in $70 \%$ of the cohort. Wild-type controls showed no signs of cardiac failure (Schroen et al., 2004).

Likewise, a targeted inactivation of osteonectin exhibited an increased incidence of cardiac rupture and failure after MI, resulting in a fourfold increase in mortality. Ostonectin-null infarcts had a disorganized granulation tissue and immature collagenous ECM. In contrast, adenoviral overexpression of osteonectin in WT mice improved the collagen maturation and prevented cardiac dilatation and dysfunction (Schellings et al., 2009).

In a similar manner, periostin-deficient mice have an increased incidence of cardiac rupture following experimental MI, associated with decreased recruitment of myofibroblasts and impaired collagen fiber formation in the lesion. However, surviving periostin-deficient mice have less fibrosis and significantly better cardiac performance (Matsui et al., 2010; Oka et al., 2007; Shimazaki et al., 2008).

By contrast, the effect of tenascin-C depletion on cardiac healing and remodeling after experimental MI was that end-diastolic pressure, ventricle dimension and myocardial stiffness were less increased of KO+MI compared to WT+MI mice (Nishioka et al., 2010). Histological examination revealed normal tissue healing, but interstitial fibrosis in the residual myocardium of the peri-infarcted areas was significantly less pronounced in $\mathrm{KO}+\mathrm{MI}$ mice than in WT+MI mice (Nishioka et al., 2010), perhaps due to the delayed appearance of myofibroblast in tenascin-C-deficient mice (Tamaoki et al., 2005). 


\subsection{Effect of matricellular proteins in the inflammatory response}

Given that atherosclerosis, TV, cellular and humoral rejection as all chronic inflammatory conditions, it deserves focus to also discuss the role of matricellular proteins in this context.

\subsubsection{Osteopontin}

Osteopontin affects inflammatory responses at many different levels (reviewed in Lund et al., 2009 and Scatena et al., 2007). First, osteopontin plays a crucial key role in macrophage biology by regulating migration, survival, phagocytosis, and pro-inflammatory cytokine production in vitro (Lund et al., 2009; Weber et al., 2002). Conversely, osteopontin is induced by several inflammatory cytokines in macrophages, including TNF- $\alpha$, IL- $1 \beta$, IFN- $\gamma$, and IL-6, and other factors such as angiotensin-II, oxidizedLDL, and phorbol-ester (Lund et al., 2009). In CD4+ and CD8+ lymphocytes, osteopontin is strongly induced in response to $\mathrm{T}$ cell receptor ligation (Shinohara et al., 2005). In vivo, subcutaneous injection of ostopontin leads to recruitment of macrophages (Giachelli et al., 1998) and in osteopontin-deficient mice, macrophage infiltration is greatly diminished compared to wild-type mice in both acute and chronic inflammation models such as unilateral uretheral obstruction (UUO) model (Ophascharoensuk et al., 1999) or type II collagen antibody-induced arthritis (Yumoto et al., 2002). Osteopontin has also been also reported to regulate $T$ cells migration, adhesion, costimulation and proliferation (O'Regan et al., 1999; Patarca et al., 1993) as well as migration of neutrophils (Koh et al., 2007) and dendritic cells (Weiss et al., 2001). Moreover, osteopontin can modulate the immune response by enhancing expression of Th1 cytokines by promoting expression of IL-12 and inhibiting that of IL-10 (Ashkar et al., 2000). In addition, there is evidence that matrix degrading enzymes are affected, as matrix metalloprotease (MMP)-2 and MMP-9 activity was reduced after angiotensin II infusion in osteopontin KO mice (Bruemmer et al., 2003) and macrophages stimulated with osteopontin in vitro upregulated activated MMP-9 (Weber et al., 2002).

\subsubsection{Tenascin C}

Midwood and coworkers reported recently that tenascin- $C$, acting as an endogenous activator of TLR4-mediated immunity, mediates persistent synovial inflammation and tissue destruction in arthritic joint disease (Midwood et al., 2009). In vitro, TLR4 ligation also stimulated synthesis of TNF- $\alpha$, IL-6 and IL-8 in primary human macrophages and IL-6 in synovial fibroblasts. TLR4-binding has been mapped to the FBG domain of tenascin-C at the carboxy terminus of the molecule. Interestingly, tenascin- $C$ does not seem to be involved in the initiation of inflammation but it is required for the maintenance of joint inflammation, perhaps reflecting that it is absent from healthy tissue and needs induction by inflammatory mediators (Goh et al., 2010). The key role of tenascin-C in prolonging joint inflammation was underscored by the protection of tenasin C-/- mice from sustained and erosive joint inflammation (Midwood et al., 2009). Tenascin C can also stimulate cytokine synthesis in murine synovial fibroblasts via activation of a9 integrins (Kanayama et al., 2009).

Moreover, tenascin-C appears to be involved in regulation of lymphocyte migration as it supports adhesion and rolling of primary human peripheral blood and tonsillar lymphocytes (Clark et al., 1997). In addition, tenascin-C KO mice exhibit reduced lymphocyte infiltration and lower levels of IFN, TNF and IL-4 mRNA upon concanavalin A- 
induced liver injury (El-Karef et al., 2007). Furthermore, tenascin-C may be involved in lymphocyte activation although both stimulatory and inhibitory effects have been reported. Tenascin-C significantly stimulates the secretion of IL-5, IL-13, IFN-g and immunoglobulinE from spleen lymphocytes (Nakahara et al., 2006). However, it has inhibitory effect on the anti CD3-induced activation of human peripheral blood $\mathrm{T}$ cells irrespectively of costimulatory molecules used (Hemesath et al., 1994; Hibino et al, 1998) and it was also found to inhibit T cell activation induced by alloantigens (Ruegg et al., 1989).

Conversely, Tenascin-C synthesis is a target of inflammatory stimuli: it is specifically induced in immune myeloid cells by ligands to TLRs located at the cell surface (TLR2, 4, and 5), but not by those targeting TLRs in the endosome; (TLR3 or TLR8) (Goh et al., 2010). Tenascin- $C$ expression is rapidly and transiently induced in immune myeloid cells in response to tissue injury and infection (Midwood \& Orend, 2009). It therefore appears that induction of tenascin- $\mathrm{C}$ in an inflammatory setting would drive TLR4 activation leading to synthesis of more tenascin-C, perhaps resulting in a nonresolving loop of chronic inflammation (Goh et al., 2010).

\subsection{Matricellular protein's role in the TGF- $\beta$ signaling pathway}

TGF- $\beta$ is pivotal in TV and in fibrosis in general. Several matricellular proteins are involved in promoting TGF signalling. They are either involved in promoting synthesis of TGF (osteonectin, periostin), activating of the cytokine itself (thrombospondin-1 and possibly periostin) or enhancing the signalling of its receptor (osteonectin). In addition, some matricellular proteins are downstream targets of TGF signalling (CCN2). To enhance understanding of the different modes of action it is necessary to explain the complex pathway of TGF activation: Precursors of the TGF- $\beta$ isoforms 1 to 3 are cleaved by a furin protease to generate mature TGF- $\beta$ and its propeptide, also known as latency-associated peptide (LAP). LAP and mature TGF- $\beta$ remain noncovalently associated in a complex called the small latency complex (SLC), and in this form, TGF- $\beta$ remains inactive. The LAPs then binds to one of the latent TGF- $\beta$-binding proteins (LTBPs) to form large latent complexes (LLCs). The LTBPs bind to ECM proteins including fibrillins and fibronectin, thereby incorporating the different latent TGF- $\beta$ isoforms into extracellular matrices. There are several mechanisms for activation, one of them involving thrombospondin-1 binding and LAP dissociation (Hynes, 2009).

Thrombospondin-1-induced activation of TGF- $\beta$ was reported for first time in 1992 by Murphy-Ullrich and coworkers (Murphy-Ullrich et al., 1992) and since then thrombospondin-1 domains responsible for TGF binding have been identified (reviewed $\mathrm{H}$. Chen, Herndon, \& Lawler, 2000). The significance of this process confirmed both in vitro and in vivo, including angiotensin II-induced upregulation of thrombospondin leading to TGF- $\beta$ activation by cardiac and renal cells (Zhou et al., 2006) as well as a role for thrombospondin-1 in mesangial proliferative glomerulonephritis (Daniel et al., 2004) and diabetic nephropathy (Daniel et al., 2007).

Osteonectin/SPARC acts at two levels: first, it is involved in stimulating TGF production (Schiemann et al., 2003) and second, osteonectin modulates the TGF- $\beta 1$-dependent phosphorylation of Smad-2 in primary mesangial cells through an interaction with the TGF$\beta 1$-receptor complex, but only in the presence of TGF- $\beta 1$ bound to its cognate type II 
receptor (Francki et al., 2004). Osteonectin mediated modulation TGF- $\beta$ signaling has been also shown in cardiac fibroblasts in vitro. Most importantly, infusion of TGF- $\beta$ can rescue the cardiac rupture phenotype in osteonectin-null mice (Schellings et al., 2009).

In a recently published study Sidhu and coworkers demonstrated increased TGF- $\beta$ production and enhanced TGF- $\beta$ bioactivity both in periostin-overexpressing epithelial cells and in primary airway epithelial cells stimulated with recombinant periostin and suggested that periostin is an upstream regulator of TGF- $\beta$ activation in a mechanism involving MMP2 and -9 (Sidhu et al., 2010). On the other hand, CCN2/CTGF acts as a downstream mediator of TGF- $\beta$-induced fibroblasts proliferation, myofibroblast differentiation (Grotendorst et al., 2004; Kothapalli et al., 1997) and collagen synthesis (Duncan et al., 1999). CTGF synthesis is induced by TGF- $\beta$ in fibroblasts via a unique TGF- $\beta$ response element in the CTGF promoter, and blockade of CTGF synthesis or action effectively inhibits these TGF- $\beta$ effects on fibroblasts. Further research has revealed that the two domains of CTGF function mediate two distinct biological effects, the N-terminal domain myofibroblast differentiation and collagen synthesis and the C-terminal domain fibroblast proliferation (Grotendorst \& Duncan, 2005). Interestingly, another member of CCN family - CCN3 (Nov) may act as an endogenous negative regulator of CCN2 with the capacity to limit the overproduction of extracellular matrix (ECM), and thus prevent or ameliorate fibrosis (Riser et al., 2010). Overexpression of the CCN3 gene in mesangial cells markedly down-regulates CCN2 activity and blocks ECM over-accumulation stimulated by TGF- $\beta 1$. Conversely, TGF- $\beta 1$ treatment reduces endogenous $\mathrm{CCN} 3$ expression and increases CCN2 activity and matrix accumulation (Riser et al., 2010). Additionally, when cultured mesangial cells are exposed to exogenous CCN3 protein, TGF- $\beta$ stimulated increase in CCN2 is attenuated in a dose-dependent manner (Riser et al., 2009).

Osteopontin, similar to CCN2, also mediates the TGF- $\beta$ signaling involved in the differentiation of fibroblasts into myofibroblasts. This conclusion is based on the observation that a-smooth muscle actin is not expressed in TGF- $\beta$-treated cardiac fibroblasts isolated from osteopontin-null mice and additionally confirmed by small interfering RNA knockdown of osteopontin in fibroblasts from wild-type mice (Lenga et al., 2008).

\subsection{Matricellular proteins in myofibroblast differentiation and SMC recruitment}

TGF- $\beta$ is thought to provide a crucial signal that initiates differentiation of myofibroblasts (Leask, 2010), partly acting by altering focal adhesion kinase activatity, up-regulating expression of integrin receptors and induction of the fibronectin splice variant ectodomain (ED)-A (Ffrench-Constant et al., 1989; Serini et al., 1998). While matricelular proteins can influence myofibroblast differentiation via modulation of TGF- $\beta$ signalling as described in previous section, there is growing evidence that matricellular proteins can influence fibroblast recruitment and differentiation also by other mechanisms.

\subsubsection{Tenascin C}

Tamaoki and coworkers, studying tissue repair after myocardial injury observed that the appearance of myofibroblasts was delayed in tenascin-C KO mice, although myocardial repair appeared to proceed normally. Moreover, cardiac fibroblasts from tenascin-C KO mice showed lower cell migration and a-SMA expression than WT cells that synthesize 
tenascin- $C$ in culture. Addition of tenascin- $C$ to tenascin-C-null cells recovered both cell migration and a-SMA expression. Functional domains of tenascin- $C$ protein responsible for inducing myofibroblast differentiation were mapped to alternatively spliced FNIII repeats (but not the conserved repeats) and the FGB domain. In contrast, the molecular signal that promoted migration of cardiac fibroblasts was mapped to the domain of conserved FNIII repeats and the FGB domain (Tamaoki et al., 2005).

\subsubsection{Periostin}

Recently, Shimazaki and coworkers reported that impaired cardiac healing after an acute myocardial infarction in periostin-KO mice was associated with reduced numbers of alpha smooth muscle actin-positive cells. The authors suggested a model in which periostin signals via av-integrin, FAK, and Akt, activates cell migration of cardiac fibroblasts from outside into the infarct region, and then supports their differentiation into aSMA-positive fibroblasts, resulting in enhanced stiffness of the LV wall through collagen synthesis after AMI (Shimazaki et al., 2008). Interestingly, periostin has been shown also to mediate vascular smooth muscle cell migration through mechanisms similar to those described above engaging the integrins $\operatorname{av} \beta 3$ and $\alpha v \beta 5$ and focal adhesion kinase (FAK) pathway (Li et al., 2010).

\subsection{Matricellular proteins in ECM assembly and collagen fibrillogenesis}

An identification of the factors that control collagen fibril formation and ECM assembly is critical for an understanding of tissue organization and the mechanisms that lead to fibrosis. There is growing evidence that matricellular proteins may play an important role in these processes not only via effects on TGF- $\beta$ signaling pathway. Below we have listed a few examples suggesting potential mechanisms of matricellular proteins involvement in collagen synthesis and maturation.

\subsubsection{Tenascin $\mathrm{X}$ - effect on matrix mechanical properties}

A crucial role in tenascin- $X$ collagen biology is suggested by the fact that its deficiency is associated with the Ehlers-Danlos Syndrome in humans (Burch et al., 1997). Major clinical symptoms consist of skin hyperextensibility and joint laxity, while ultrastructural analyses reveal abnormalities in collagen fibril networks and elastic fibre morphology. Mice deficient in tenascin-X partly reproduced this phenotype (Mao et al., 2002). In vitro studies revealed that tenascin- $X$ interacts with fibrillar collagen type I, III and V when they are in native conformation. Additional studies indicated that both epidermal growth factor repeats and the fibrinogen-like domain are involved in this interaction (Lethias et al., 2006) and although the presence of tenascin- $X$ does not significantly influence the main parameters of fibrillogenesis and diameter of fibrils, mechanical analysis of collagen gels showed an increased compressive resistance of the gels containing tenascin- $X$, indicating that this protein might be directly involved in determining the mechanical properties of collagen-rich tissues in vivo (Margaron et al., 2010).

\subsubsection{Osteonectin - effect on procollagen I processing}

Adult osteonectin-null mice exhibit decreased amounts of collagen in skin (Bradshaw et al., 2003). In addition, fibrotic deposition of collagen in mice with bleomycin-induced 
pulmonary fibrosis is diminished in the absence of osteonectin (Strandjord et al., 1999), Moreover, Rentz and coworkers investigated collagen I production in osteonectin-null dermal fibroblasts observing that osteonectin might be involved in regulation of procollagen I processing (Rentz et al., 2007). The a1(I) and a2(I) subunits of procollagen I are synthesized with $\mathrm{N}$ - and C-propeptides that are enzymatically released by specific proteases. Processing of procollagen I to collagen I is essential for correct assembly of collagen fibrils and regulation of procollagen processing has been proposed as a potential regulatory event in collagen fibril assembly (Prockop \& Kivirikko, 1995). Although osteonectin-null dermal fibroblasts exhibited an increased association of collagen I with cell layers and enhanced processing of procollagen1(I) to collagen1(I). The processed collagen I was not efficiently incorporated into osteonectin-null detergent-insoluble cell layers, and collagen fibers that formed on osteonectin-null cells did not persist to the same extent as those on WT cells (Rentz et al., 2007).

\subsubsection{Periostin - an effect on collagen I cross-linking}

Collagen fibrils from periostin-deficient mice show reduced size, organisation, and less efficient cross-linking (Norris et al., 2007; Shimazaki et al., 2008). Recently, Maruhashi and coworkers (Maruhashi et al., 2010) proposed a model to explain periostin's role in determining ECM integrity. Collagen fibrils are stabilized by the formation of intra- and intermolecular cross-linking that is catalyzed by the enzyme lysyl oxidase (LOX). The activity of LOX is regulated by proteolytic cleavage of its inactive precursor, pro-LOX, by BMP-1 (bone morphogenetic protein-1; also known as pro-collagen C-proteinase) (Uzel et al., 2001). Periostin binds to BMP-1 and promotes the proteolytic activation of pro-LOX. As it has been shown that periostin also interacts with fibronectin (Takayama et al., 2006), the model suggest periostin-mediated scaffolding for the interaction between pro-LOX and BMP-1 on the fibronectin matrix (Maruhashi et al., 2010).

\section{Matricellular proteins in therapy}

Although modulation of matricellular protein function has not yet been subject to clinical trials, there is growing evidence from experiments in animal models that this approach can be beneficial in many diseases including fibrosis. Here, we present a few of models of experimental therapy involving matricellular proteins.

\subsection{Depletion of microcellular protein by antisense or siRNA}

Adenovirus-mediated inhibition of osteonectin markedly attenuated the development of hepatic fibrosis in rats treated with thioacetamide, as assessed by decreased collagen deposition, lower hepatic content of hydroxyproline and less advanced morphometric stage of fibrosis. Osteonectin depletion also reduced inflammatory activity and suppressed transdifferentiation of hepatic stellate cell to the myofibroblasts-like phenotype (Camino et al., 2008). In another approach, osteonectin siRNA treatment through subcutaneous injection or intratracheal instillation was found to markedly reduce fibrotic changes in skin and lungs in murine models of skin and lung fibrosis induced by bleomycin (Wang et al., 2010).

Morover, antisense oligonucleotides against thrombospondin-1 were used to inhibit activation of TGF- $\beta$ in a rat model of mesangial proliferative glomerulonephritis, in which 
TGF- $\beta$ has been demonstrated to mediate renal fibrosis. The antisense-mediated reduction of thrombospondin did not reduce the expression of TGF- $\beta$ but rather inhibited the TGF- $\beta$ dependent smad-signalling pathway, as well as the transcription of TGF-beta target genes, resulting in a markedly suppressed accumulation of extracellular matrix (Daniel et al., 2003).

\subsection{Modification of matricellular protein function by antagonist}

In a rat model of type 1 diabetes in which diabetic cardiomyopathy is exacerbated by abdominal aortic coarctation, Belmadani and coworkers observed that a peptide antagonist of thrombospondin-1-dependent TGF- $\beta$ activation prevented progression of cardiac fibrosis and improved cardiac function (Belmadani et al., 2007). In an analogous experiment, treatment with a peptide antagonist of thrombospondin-1 attenuated renal interstitial fibrosis in rats with unilateral ureteral obstruction (Xie et al., 2010).

\subsection{Overexpression of matricellular protein}

Thrombospondin-2 overexpression via thigh muscle transfection was studied in the anti-Thy1 glomerulonephritis model. Muscular overexpression of thrombospondin-2 reduced glomerular TGF- $\beta$ activation and glomerular extracellular matrix formation as determined by collagen IV and fibronectin. In addition, activation of mesangial cells to the myofibroblast-like phenotype was also significantly decreased in thrombospondin-2-overexpressing animals (Daniel, Wagner, Hohenstein, \& Hugo, 2009). Additionally, thrombospondin 1 overexpression was suggested as a gene therapeutic strategy in collagen-induced arthritis (CIA). Direct intraarticular administration of adenoviral vectors encoding thrombospondin- 1 significantly ameliorated the clinical course of CIA in rat model (Jou et al., 2005).

\section{Models of fibrosis}

Animal models of chronic allograft injury have been comprehensively described in a recent review (Bedi et al., 2010).

\subsection{Heterotopic cardiac transplantation}

The model of heterotopic cardiac transplantation is and has been widely used to study chronic allograft injury and rejection. It also provides information relevant to graft ischemiareperfusion injury, allorejection and immunosuppressants, as well as physiologic changes that take place post-transplant in vascularized organs. In comparison to orthotopic transplantation, the heterotopic procedure is technically less demanding and does not require a cardiopulmonary bypass. After pioneer transplantation experiments in large animals, Abbott et al. described a method of vascularised abdominal heterotopic heart transplantation in rats in 1964 (Abbott et al., 1964). Ono and Lindsay improved the technique by end-to-side anastomosis of the donor vessels to the recipient's aorta and IVC, resulting in a higher recipient survival rate (Ono \& Lindsey, 1969). This method has been widely used, adopted to use in mice and improved by several modifications (Hasegawa et al., 2007; Shan et al., 2010).

Of particular relevance to TV, Adams et al. described cardiac allografting across minor histocompatibility barriers (Lewis-F344 model) (Adams et al., 1993). Advantages of the 
Lewis-F344 model are commercial availability and easily recognizable inflammatory stages of lesion development. On the other hand, grafts have relatively low long-term survival rates $(25 \%)$ and they show substantially more severe mononuclear infiltration and necrosis when compared to human TV lesions (Adams et al., 1993), unless they were exposed to high levels of cyclosporin, in which case TV failed to develop (Poston et al., 1999). Although the Lewis-F344 model remains commonly used, Poston et al. argued that a model in which TV developed despite immunosuppression, would more appropriately reflect a situation where cell mediated alloimmunity is not the sole or major pathogenesis (Poston et al., 1999). This situation is seen in the PVG (Piebald Viral Glaxo, RT1c)-to-ACI (August Copenhagen Irish, RT1a) which is a fully-mismatched MHC class II model. However, a disadvantage of the PVG-to-ACI model is that it fails to induce myocardial rejection. Nevertheless, in this model, rapamycin, but not cyclosporin, is capable of reducing the degree of chronic graft vascular disease and opens the door for investigators to study chronic injury in a model that is relatively resistant to T-cell- directed immunosuppressants (like cyclosporin) but susceptible to novel agents whose mechanism of actions lies beyond reduction in T-cellmediated immunity.

Murine models of chronic allograft injury include those involving different strains with minor histoincompatibilities, which usually leads to a smoldering immunologic response within the allograft and ultimately, chronic injury (Bedi et al., 2010).

An established mouse model of TV is an MHC class II-mismatched heterotopic graft from B6.C.H-2-bm12 (bm12) into a wild-type C57BL/6 (B6, H-2b) mouse. Bm12 mice are a variant strain of C57BL/ 6 mice, in which a spontaneous mutation has occurred in the I-Ab locus, designated I-Abm12. In this single MHC class II mismatch model, the majority of bm12 cardiac allografts survive up to 100 days and develop significant vasculopathy, notable for intraluminal accumulation of mononuclear leukocytes (at 4 weeks posttransplant), intimal lesions (by 8 weeks), and accumulation of smooth muscle cells signifying fibroproliferative arteriosclerotic lesions (by 12 weeks; Fig. 2). The limited alloreactive T-cell activation and emergence of a population of regulatory $\mathrm{T}$ cells allow long-term allograft survival with the development of significant vasculopathy (Bedi et al., 2010).

As in rat models, heterotopic cardiac transplantation between fully MHC-mismatched mouse strains has been described as models for studying chronic rejection with the use of postoperative immunosuppressants to prevent acute rejection. In one model, anti-CD40L is administered after B6-to- BALB/c $(\mathrm{H} 2 \mathrm{~d})$ heterotopic cardiac transplantation. Without manipulation, cardiac allografts are promptly rejected; however, if treated with anti-CD40L, acute rejection is ameliorated, and recipients develop chronic rejection. In this model, approximately $50 \%$ of cardiac allografts survive 100 days, but with severe evidence of histologic chronic allograft changes (Bedi et al., 2010).

\subsection{Aorta transplantation}

Abdominal aorta transplantation has been widely used in rodents as a model for TV (i.e. Murphy, Bicknell, \& Nicholson, 2003)) and involves substitution of a part of the recipient's distal aorta with a donor graft. One of the first aortic allograft models for chronic rejection in the rat was described by Mennader (Mennander et al., 1991) and Isik (Isik et al., 1992). They revealed histologic features that parallel those seen in the vessels of human transplanted 
organs (Isik et al., 1992). Similar methods in mice have been described by Koulack et al. (Koulack et al., 1995) and have been further modified (i.e. (Ensminger et al., 2002)). The histologic features are an initial increase in mononuclear inflammatory cells with gradually increasing numbers of smooth muscle cells resulting in intimal thickening of the aorta and at later time points in deposition of extracellular matrix and collagen fibrils (Isik et al., 1992).

Aortic allografts transplantation represents an alternative model for evaluation of the influence of novel transplant strategies on transplant arteriosclerosis. Vascular changes can be easily and more precisely quantified due to faciliated access to the aortic graft thus providing representative sections (Isik et al., 1992; Mennander et al., 1991). In contrast, quantification of TV in rat and mouse cardiac allografts is reportedly difficult and the interpretation of the data obtained controversial (Ensminger et al., 2000; Isik et al., 1992).

The aortic transplantation is a useful model for the study of vascular repair. Due to the absence of the impact of supporting parenchyma it is questionable whether vascular changes in aortic allografts are representative for chronic vascular rejection in solid-organ transplants (Libby \& Pober, 2001). Nevertheless, Ensminger et al. reported in a combined cardiac and aortic transplant model on equivalent outcome of TV in abdominal aortic allografts in the presence as well as in the absence of an additional organ transplant (Ensminger et al., 2000). Moreover, although heterotopic cardiac transplantation might be a more suitable model, the aortic transplantation model is helpful in understanding the endothelial milieu during chronic allograft injury.

\subsection{Other models of cardiac fibrosis}

Most other models of cardiac fibrosis involve mechanic or pharmacologic intervention aimed at increasing the cardiac workload. The mechanic approach involves partial constriction at various levels of the aortic arch. The pharmacologic approach involves the infusion of angiotensin or aldosterone. Angiotensin treatment leads to fibrosis development within 2 weeks and increases with time (Sun \& Weber, 2005), whereas the aldosterone model also requires reduction of functional kidney mass (unilateral nephrectomy) and subsequent high sodium diet, therefore requiring more than 4 weeks to develop fibrosis (Sun \& Weber, 2005).

\subsection{Selected features of non-cardiac models of fibrosis}

A large number of fibrosis models in other organs have been described and are thought to have particular relevance to fibrosis in that specific organ. Inducing agents can be alloreactivity, chemical irritants, high-fat diet (relevant to liver fibrosis) or secretory obstruction (bile or urine). However, it is worth noting that a comparison between organs may provide a more efficient search for core pathways essential to convert an initial stimulus to the development of fibrosis (Mehal et al., 2011). Likewise, none of the models, currently considered relevant to understanding cardiac fibrosis development, are well suited for "high-throughput" analyses because they are technically demanding and require a relatively long time to develop the lesion.

Unilateral ureteral obstruction (UUO) is an inducible animal model in rodents for human obstructive nephropathy leading to tubolointerstitial fibrosis. It has become a standard model of nonimmunological tubulointerstitial fibrosis in which the ureter of one kidney is 
obstructed by ligation. Obstruction can be partial or total. With complete obstruction, fibrosis can generally be observed within 1-2 weeks, depending on the species and strain used in the experimental setting. A substantial advantage of the UUO model over complex transplantation models is technical simplicity and a relatively short time required to develop the lesions. Other assets are absence of exogenous toxin and the contralateral organ serving as control (Chevalier et al., 2009).

\section{Conclusion}

Transplant vasculopathy and interstitial fibrosis remain key clinical obstacles to achieve long-term survival of solid organ allografts. Although to date relatively little data has been generated to address the role of matricellular proteins directly in this context, there is considerable circumstantial evidence from surrounding fields to foresee that their functions may be central to allograft-associated fibrosis development. Several models of cardiac fibrosis are well-established but time consuming. This limitation may be seen in light of the recently proposed strategy to identify core pathways of fibrosis by simultaneously comparing the process in several different organs.

\section{References}

Abbott, C. P., Lindsey, E. S., Creech, O., Jr., \& Dewitt, C. W. (1964). A Technique for Heart Transplantation in the Rat. Arch Surg, 89, 645-652.

Adams, D. H., Russell, M. E., Hancock, W. W., Sayegh, M. H., Wyner, L. R., \& Karnovsky, M. J. (1993). Chronic rejection in experimental cardiac transplantation: studies in the Lewis-F344 model. Immunol Rev, 134, 5-19.

Adams, J. C., \& Lawler, J. (2004). The thrombospondins. Int J Biochem Cell Biol, 36(6), 961-968.

Ashkar, S., Weber, G. F., Panoutsakopoulou, V., Sanchirico, M. E., Jansson, M., Zawaideh, S., et al. (2000). Eta-1 (osteopontin): an early component of type-1 (cell-mediated) immunity. Science, 287(5454), 860-864.

Bedi, D. S., Riella, L. V., Tullius, S. G., \& Chandraker, A. (2010). Animal models of chronic allograft injury: contributions and limitations to understanding the mechanism of long-term graft dysfunction. Transplantation, 90(9), 935-944.

Belmadani, S., Bernal, J., Wei, C. C., Pallero, M. A., Dell'italia, L., Murphy-Ullrich, J. E., et al. (2007). A thrombospondin-1 antagonist of transforming growth factor-beta activation blocks cardiomyopathy in rats with diabetes and elevated angiotensin II. Am J Pathol, 171(3), 777-789.

Bornstein, P. (1995). Diversity of function is inherent in matricellular proteins: an appraisal of thrombospondin 1. J Cell Biol, 130(3), 503-506.

Bornstein, P., \& Sage, E. H. (2002). Matricellular proteins: extracellular modulators of cell function. Curr Opin Cell Biol, 14(5), 608-616.

Bradshaw, A. D., Puolakkainen, P., Dasgupta, J., Davidson, J. M., Wight, T. N., \& Helene Sage, E. (2003). SPARC-null mice display abnormalities in the dermis characterized by decreased collagen fibril diameter and reduced tensile strength. J Invest Dermatol, 120(6), 949-955.

Brekken, R. A., \& Sage, E. H. (2000). SPARC, a matricellular protein: at the crossroads of cellmatrix. Matrix Biol, 19(7), 569-580. 
Bruemmer, D., Collins, A. R., Noh, G., Wang, W., Territo, M., Arias-Magallona, S., et al. (2003). Angiotensin II-accelerated atherosclerosis and aneurysm formation is attenuated in osteopontin-deficient mice. J Clin Invest, 112(9), 1318-1331.

Burch, G. H., Gong, Y., Liu, W., Dettman, R. W., Curry, C. J., Smith, L., et al. (1997). Tenascin-X deficiency is associated with Ehlers-Danlos syndrome. Nat Genet, 17(1), 104-108.

Camino, A. M., Atorrasagasti, C., Maccio, D., Prada, F., Salvatierra, E., Rizzo, M., et al. (2008). Adenovirus-mediated inhibition of SPARC attenuates liver fibrosis in rats. J Gene Med, 10(9), 993-1004.

Chen, C. C., \& Lau, L. F. (2009). Functions and mechanisms of action of CCN matricellular proteins. Int J Biochem Cell Biol, 41(4), 771-783.

Chen, H., Herndon, M. E., \& Lawler, J. (2000). The cell biology of thrombospondin-1. Matrix Biol, 19(7), 597-614.

Chevalier, R. L., Forbes, M. S., \& Thornhill, B. A. (2009). Ureteral obstruction as a model of renal interstitial fibrosis and obstructive nephropathy. Kidney Int, 75(11), 1145-1152.

Chiquet-Ehrismann, R., \& Chiquet, M. (2003). Tenascins: regulation and putative functions during pathological stress. J Pathol, 200(4), 488-499.

Clark, R. A., Erickson, H. P., \& Springer, T. A. (1997). Tenascin supports lymphocyte rolling. J Cell Biol, 137(3), 755-765.

Conway, S. J., \& Molkentin, J. D. (2008). Periostin as a heterofunctional regulator of cardiac development and disease. Curr Genomics, 9(8), 548-555.

Cox, T. R., \& Erler, J. T. (2011). Remodeling and homeostasis of the extracellular matrix: implications for fibrotic diseases and cancer. Dis Model Mech, 4(2), 165-178.

Daniel, C., Schaub, K., Amann, K., Lawler, J., \& Hugo, C. (2007). Thrombospondin-1 is an endogenous activator of TGF-beta in experimental diabetic nephropathy in vivo. Diabetes, 56(12), 2982-2989.

Daniel, C., Takabatake, Y., Mizui, M., Isaka, Y., Kawashi, H., Rupprecht, H., et al. (2003). Antisense oligonucleotides against thrombospondin-1 inhibit activation of tgf-beta in fibrotic renal disease in the rat in vivo. Am J Pathol, 163(3), 1185-1192.

Daniel, C., Wagner, A., Hohenstein, B., \& Hugo, C. (2009). Thrombospondin-2 therapy ameliorates experimental glomerulonephritis via inhibition of cell proliferation, inflammation, and TGF-beta activation. Am J Physiol Renal Physiol, 297(5), F12991309.

Daniel, C., Wiede, J., Krutzsch, H. C., Ribeiro, S. M., Roberts, D. D., Murphy-Ullrich, J. E., et al. (2004). Thrombospondin-1 is a major activator of TGF-beta in fibrotic renal disease in the rat in vivo. Kidney Int, 65(2), 459-468.

Duncan, M. R., Frazier, K. S., Abramson, S., Williams, S., Klapper, H., Huang, X., et al. (1999). Connective tissue growth factor mediates transforming growth factor betainduced collagen synthesis: down-regulation by cAMP. Faseb J, 13(13), 1774-1786.

El-Karef, A., Yoshida, T., Gabazza, E. C., Nishioka, T., Inada, H., Sakakura, T., et al. (2007). Deficiency of tenascin-C attenuates liver fibrosis in immune-mediated chronic hepatitis in mice. J Pathol, 211(1), 86-94.

Elefteriou, F., Exposito, J. Y., Garrone, R., \& Lethias, C. (1999). Cell adhesion to tenascin-X mapping of cell adhesion sites and identification of integrin receptors. Eur $J$ Biochem, 263(3), 840-848. 
Ellison, J. A., Velier, J. J., Spera, P., Jonak, Z. L., Wang, X., Barone, F. C., et al. (1998). Osteopontin and its integrin receptor alpha(v)beta3 are upregulated during formation of the glial scar after focal stroke. Stroke, 29(8), 1698-1706; discussion 1707.

Ensminger, S. M., Billing, J. S., Morris, P. J., \& Wood, K. J. (2000). Development of a combined cardiac and aortic transplant model to investigate the development of transplant arteriosclerosis in the mouse. J Heart Lung Transplant, 19(11), 1039-1046.

Ensminger, S. M., Spriewald, B. M., Witzke, O., Morrison, K., Pajaro, O. E., Morris, P. J., et al. (2002). Kinetics of transplant arteriosclerosis in MHC-Class I mismatched and fully allogeneic mouse aortic allografts. Transplantation, 73(7), 1068-1074.

Ffrench-Constant, C., Van de Water, L., Dvorak, H. F., \& Hynes, R. O. (1989). Reappearance of an embryonic pattern of fibronectin splicing during wound healing in the adult rat. J Cell Biol, 109(2), 903-914.

Fischer, J. W. (2007). Tenascin-C: a key molecule in graft stenosis. Cardiovasc Res, 74(3), 335336.

Francki, A., McClure, T. D., Brekken, R. A., Motamed, K., Murri, C., Wang, T., et al. (2004). SPARC regulates TGF-beta1-dependent signaling in primary glomerular mesangial cells. J Cell Biochem, 91(5), 915-925.

Frangogiannis, N. G., Ren, G., Dewald, O., Zymek, P., Haudek, S., Koerting, A., et al. (2005). Critical role of endogenous thrombospondin-1 in preventing expansion of healing myocardial infarcts. Circulation, 111(22), 2935-2942.

Franz, M., Grun, K., Richter, P., Brehm, B. R., Fritzenwanger, M., Hekmat, K., et al. (2010). Extra cellular matrix remodelling after heterotopic rat heart transplantation: gene expression profiling and involvement of ED-A+ fibronectin, alpha-smooth muscle actin and $\mathrm{B}+$ tenascin-C in chronic cardiac allograft rejection. Histochem Cell Biol, 134(5), 503-517.

Gamba, A., Mammana, C., Fiocchi, R., Iamele, L., \& Mamprin, F. (2000). Cyclosporine and graft coronary artery disease after heart transplantation. Compr Ther, 26(2), 121-126.

Geffrotin, C., Garrido, J. J., Tremet, L., \& Vaiman, M. (1995). Distinct tissue distribution in pigs of tenascin-X and tenascin-C transcripts. Eur J Biochem, 231(1), 83-92.

Giachelli, C. M., Bae, N., Almeida, M., Denhardt, D. T., Alpers, C. E., \& Schwartz, S. M. (1993). Osteopontin is elevated during neointima formation in rat arteries and is a novel component of human atherosclerotic plaques. J Clin Invest, 92(4), 1686-1696.

Giachelli, C. M., Lombardi, D., Johnson, R. J., Murry, C. E., \& Almeida, M. (1998). Evidence for a role of osteopontin in macrophage infiltration in response to pathological stimuli in vivo. Am J Pathol, 152(2), 353-358.

Goh, F. G., Piccinini, A. M., Krausgruber, T., Udalova, I. A., \& Midwood, K. S. (2010). Transcriptional regulation of the endogenous danger signal tenascin-C: a novel autocrine loop in inflammation. J Immunol, 184(5), 2655-2662.

Greenwood, J. A., \& Murphy-Ullrich, J. E. (1998). Signaling of de-adhesion in cellular regulation and motility. Microsc Res Tech, 43(5), 420-432.

Grotendorst, G. R., \& Duncan, M. R. (2005). Individual domains of connective tissue growth factor regulate fibroblast proliferation and myofibroblast differentiation. Faseb J, 19(7), 729-738. 
Grotendorst, G. R., Rahmanie, H., \& Duncan, M. R. (2004). Combinatorial signaling pathways determine fibroblast proliferation and myofibroblast differentiation. Faseb J, 18(3), 469-479.

Hasegawa, T., Visovatti, S. H., Hyman, M. C., Hayasaki, T., \& Pinsky, D. J. (2007). Heterotopic vascularized murine cardiac transplantation to study graft arteriopathy. Nat Protoc, 2(3), 471-480.

Hemesath, T. J., Marton, L. S., \& Stefansson, K. (1994). Inhibition of T cell activation by the extracellular matrix protein tenascin. J Immunol, 152(11), 5199-5207.

Hibino, S., Kato, K., Kudoh, S., Yagita, H., \& Okumura, K. (1998). Tenascin suppresses CD3mediated T cell activation. Biochem Biophys Res Commun, 250(1), 119-124.

Hinz, B. (2010). The myofibroblast: paradigm for a mechanically active cell. J Biomech, 43(1), 146-155.

Hynes, R. O. (2009). The extracellular matrix: not just pretty fibrils. Science, 326(5957), 12161219.

Imanaka-Yoshida, K., Hiroe, M., Nishikawa, T., Ishiyama, S., Shimojo, T., Ohta, Y., et al. (2001). Tenascin-C modulates adhesion of cardiomyocytes to extracellular matrix during tissue remodeling after myocardial infarction. Lab Invest, 81(7), 1015-1024.

Imanaka-Yoshida, K., Hiroe, M., Yasutomi, Y., Toyozaki, T., Tsuchiya, T., Noda, N., et al. (2002). Tenascin-C is a useful marker for disease activity in myocarditis. J Pathol, 197(3), 388-394.

Isik, F. F., McDonald, T. O., Ferguson, M., Yamanaka, E., \& Gordon, D. (1992). Transplant arteriosclerosis in a rat aortic model. Am J Pathol, 141(5), 1139-1149.

Jou, I. M., Shiau, A. L., Chen, S. Y., Wang, C. R., Shieh, D. B., Tsai, C. S., et al. (2005). Thrombospondin 1 as an effective gene therapeutic strategy in collagen-induced arthritis. Arthritis Rheum, 52(1), 339-344.

Kanayama, M., Kurotaki, D., Morimoto, J., Asano, T., Matsui, Y., Nakayama, Y., et al. (2009). Alpha9 integrin and its ligands constitute critical joint microenvironments for development of autoimmune arthritis. J Immunol, 182(12), 8015-8025.

Khanna, A. (2005). Tacrolimus and cyclosporinein vitro and in vivo induce osteopontin mRNA and protein expression in renal tissues. Nephron Exp Nephrol, 101(4), e119126.

Kii, I., Nishiyama, T., Li, M., Matsumoto, K., Saito, M., Amizuka, N., et al. (2010). Incorporation of tenascin-C into the extracellular matrix by periostin underlies an extracellular meshwork architecture. J Biol Chem, 285(3), 2028-2039.

Koh, A., da Silva, A. P., Bansal, A. K., Bansal, M., Sun, C., Lee, H., et al. (2007). Role of osteopontin in neutrophil function. Immunology, 122(4), 466-475.

Komatsubara, I., Murakami, T., Kusachi, S., Nakamura, K., Hirohata, S., Hayashi, J., et al. (2003). Spatially and temporally different expression of osteonectin and osteopontin in the infarct zone of experimentally induced myocardial infarction in rats. Cardiovasc Pathol, 12(4), 186-194.

Kothapalli, D., Frazier, K. S., Welply, A., Segarini, P. R., \& Grotendorst, G. R. (1997). Transforming growth factor beta induces anchorage-independent growth of NRK fibroblasts via a connective tissue growth factor-dependent signaling pathway. Cell Growth Differ, 8(1), 61-68. 
Koulack, J., McAlister, V. C., Giacomantonio, C. A., Bitter-Suermann, H., MacDonald, A. S., \& Lee, T. D. (1995). Development of a mouse aortic transplant model of chronic rejection. Microsurgery, 16(2), 110-113.

Krishnamurthy, P., Peterson, J. T., Subramanian, V., Singh, M., \& Singh, K. (2009). Inhibition of matrix metalloproteinases improves left ventricular function in mice lacking osteopontin after myocardial infarction. Mol Cell Biochem, 322(1-2), 53-62.

Kruzynska-Frejtag, A., Machnicki, M., Rogers, R., Markwald, R. R., \& Conway, S. J. (2001). Periostin (an osteoblast-specific factor) is expressed within the embryonic mouse heart during valve formation. Mech Dev, 103(1-2), 183-188.

Kular, L., Pakradouni, J., Kitabgi, P., Laurent, M., \& Martinerie, C. (2011). The CCN family: a new class of inflammation modulators? Biochimie, 93(3), 377-388.

Leask, A. (2010). Potential therapeutic targets for cardiac fibrosis: TGFbeta, angiotensin, endothelin, CCN2, and PDGF, partners in fibroblast activation. Circ Res, 106(11), 1675-1680.

Lenga, Y., Koh, A., Perera, A. S., McCulloch, C. A., Sodek, J., \& Zohar, R. (2008). Osteopontin expression is required for myofibroblast differentiation. Circ Res, 102(3), 319-327.

Lethias, C., Carisey, A., Comte, J., Cluzel, C., \& Exposito, J. Y. (2006). A model of tenascin-X integration within the collagenous network. FEBS Lett, 580(26), 6281-6285.

Li, G., Jin, R., Norris, R. A., Zhang, L., Yu, S., Wu, F., et al. (2010). Periostin mediates vascular smooth muscle cell migration through the integrins alphavbeta3 and alphavbeta5 and focal adhesion kinase (FAK) pathway. Atherosclerosis, 208(2), 358365.

Libby, P., \& Pober, J. S. (2001). Chronic rejection. Immunity, 14(4), 387-397.

Lund, S. A., Giachelli, C. M., \& Scatena, M. (2009). The role of osteopontin in inflammatory processes. J Cell Commun Signal, 3(3-4), 311-322.

Mao, J. R., Taylor, G., Dean, W. B., Wagner, D. R., Afzal, V., Lotz, J. C., et al. (2002). Tenascin-X deficiency mimics Ehlers-Danlos syndrome in mice through alteration of collagen deposition. Nat Genet, 30(4), 421-425.

Margaron, Y., Bostan, L., Exposito, J. Y., Malbouyres, M., Trunfio-Sfarghiu, A. M., Berthier, Y., et al. (2010). Tenascin-X increases the stiffness of collagen gels without affecting fibrillogenesis. Biophys Chem, 147(1-2), 87-91.

Maruhashi, T., Kii, I., Saito, M., \& Kudo, A. (2010). Interaction between periostin and BMP-1 promotes proteolytic activation of lysyl oxidase. J Biol Chem, 285(17), 13294-13303.

Matsui, Y., Morimoto, J., \& Uede, T. (2010). Role of matricellular proteins in cardiac tissue remodeling after myocardial infarction. World J Biol Chem, 1(5), 69-80.

Mehal, W. Z., Iredale, J., \& Friedman, S. L. (2011). Scraping fibrosis: expressway to the core of fibrosis. Nat Med, 17(5), 552-553.

Mennander, A., Tiisala, S., Halttunen, J., Yilmaz, S., Paavonen, T., \& Hayry, P. (1991). Chronic rejection in rat aortic allografts. An experimental model for transplant arteriosclerosis. Arterioscler Thromb, 11(3), 671-680.

Midwood, K., Sacre, S., Piccinini, A. M., Inglis, J., Trebaul, A., Chan, E., et al. (2009). Tenascin- $\mathrm{C}$ is an endogenous activator of Toll-like receptor 4 that is essential for maintaining inflammation in arthritic joint disease. Nat Med, 15(7), 774-780.

Midwood, K. S., \& Orend, G. (2009). The role of tenascin-C in tissue injury and tumorigenesis. J Cell Commun Signal, 3(3-4), 287-310. 
Mikalsen, B., Fosby, B., Wang, J., Hammarstrom, C., Bjaerke, H., Lundstrom, M., et al. (2010). Genome-wide transcription profile of endothelial cells after cardiac transplantation in the rat. Am J Transplant, 10(7), 1534-1544.

Mitchell, R. N. (2009). Graft vascular disease: immune response meets the vessel wall. Annu Rev Pathol, 4, 19-47.

Motamed, K., \& Sage, E. H. (1998). SPARC inhibits endothelial cell adhesion but not proliferation through a tyrosine phosphorylation-dependent pathway. J Cell Biochem, 70(4), 543-552.

Murphy-Ullrich, J. E., Gurusiddappa, S., Frazier, W. A., \& Hook, M. (1993). Heparin-binding peptides from thrombospondins 1 and 2 contain focal adhesion-labilizing activity. $J$ Biol Chem, 268(35), 26784-26789.

Murphy-Ullrich, J. E., \& Hook, M. (1989). Thrombospondin modulates focal adhesions in endothelial cells. J Cell Biol, 109(3), 1309-1319.

Murphy-Ullrich, J. E., Schultz-Cherry, S., \& Hook, M. (1992). Transforming growth factorbeta complexes with thrombospondin. Mol Biol Cell, 3(2), 181-188.

Murphy, G. J., Bicknell, G. R., \& Nicholson, M. L. (2003). Rapamycin inhibits vascular remodeling in an experimental model of allograft vasculopathy and attenuates associated changes in fibrosis-associated gene expression. J Heart Lung Transplant, 22(5), 533-541.

Nakahara, H., Gabazza, E. C., Fujimoto, H., Nishii, Y., D'Alessandro-Gabazza, C. N., Bruno, N. E., et al. (2006). Deficiency of tenascin $C$ attenuates allergen-induced bronchial asthma in the mouse. Eur J Immunol, 36(12), 3334-3345.

Nishioka, T., Onishi, K., Shimojo, N., Nagano, Y., Matsusaka, H., Ikeuchi, M., et al. (2010). Tenascin-C may aggravate left ventricular remodeling and function after myocardial infarction in mice. Am J Physiol Heart Circ Physiol, 298(3), H1072-1078.

Nor, J. E., Mitra, R. S., Sutorik, M. M., Mooney, D. J., Castle, V. P., \& Polverini, P. J. (2000). Thrombospondin-1 induces endothelial cell apoptosis and inhibits angiogenesis by activating the caspase death pathway. J Vasc Res, 37(3), 209-218.

Norris, R. A., Damon, B., Mironov, V., Kasyanov, V., Ramamurthi, A., Moreno-Rodriguez, R., et al. (2007). Periostin regulates collagen fibrillogenesis and the biomechanical properties of connective tissues. J Cell Biochem, 101(3), 695-711.

Norris, R. A., Moreno-Rodriguez, R., Hoffman, S., \& Markwald, R. R. (2009). The many facets of the matricelluar protein periostin during cardiac development, remodeling, and pathophysiology. J Cell Commun Signal, 3(3-4), 275-286.

O'Regan, A. W., Chupp, G. L., Lowry, J. A., Goetschkes, M., Mulligan, N., \& Berman, J. S. (1999). Osteopontin is associated with T cells in sarcoid granulomas and has T cell adhesive and cytokine-like properties in vitro. J Immunol, 162(2), 1024-1031.

Oka, T., Xu, J., Kaiser, R. A., Melendez, J., Hambleton, M., Sargent, M. A., et al. (2007). Genetic manipulation of periostin expression reveals a role in cardiac hypertrophy and ventricular remodeling. Circ Res, 101(3), 313-321.

Ono, K., \& Lindsey, E. S. (1969). Improved technique of heart transplantation in rats. J Thorac Cardiovasc Surg, 57(2), 225-229.

Ophascharoensuk, V., Giachelli, C. M., Gordon, K., Hughes, J., Pichler, R., Brown, P., et al. (1999). Obstructive uropathy in the mouse: role of osteopontin in interstitial fibrosis and apoptosis. Kidney Int, 56(2), 571-580. 
Patarca, R., Saavedra, R. A., \& Cantor, H. (1993). Molecular and cellular basis of genetic resistance to bacterial infection: the role of the early T-lymphocyte activation1/osteopontin gene. Crit Rev Immunol, 13(3-4), 225-246.

Poston, R. S., Billingham, M., Hoyt, E. G., Pollard, J., Shorthouse, R., Morris, R. E., et al. (1999). Rapamycin reverses chronic graft vascular disease in a novel cardiac allograft model. Circulation, 100(1), 67-74.

Prockop, D. J., \& Kivirikko, K. I. (1995). Collagens: molecular biology, diseases, and potentials for therapy. Annu Rev Biochem, 64, 403-434.

Racanelli, A. L., Diemer, M. J., Dobies, A. C., Dubin, J. R., \& Reilly, T. M. (1992). Comparison of recombinant plasminogen activator inhibitor-1 and epsilon amino caproic acid in a hemorrhagic rabbit model. Thromb Haemost, 67(6), 692-696.

Rentz, T. J., Poobalarahi, F., Bornstein, P., Sage, E. H., \& Bradshaw, A. D. (2007). SPARC regulates processing of procollagen $\mathrm{I}$ and collagen fibrillogenesis in dermal fibroblasts. J Biol Chem, 282(30), 22062-22071.

Rhodes, J. M., \& Simons, M. (2007). The extracellular matrix and blood vessel formation: not just a scaffold. J Cell Mol Med, 11(2), 176-205.

Rickenbacher, P. R., Kemna, M. S., Pinto, F. J., Hunt, S. A., Alderman, E. L., Schroeder, J. S., et al. (1996). Coronary artery intimal thickening in the transplanted heart. An in vivo intracoronary untrasound study of immunologic and metabolic risk factors. Transplantation, 61(1), 46-53.

Riser, B. L., Najmabadi, F., Perbal, B., Peterson, D. R., Rambow, J. A., Riser, M. L., et al. (2009). CCN3 (NOV) is a negative regulator of CCN2 (CTGF) and a novel endogenous inhibitor of the fibrotic pathway in an in vitro model of renal disease. Am J Pathol, 174(5), 1725-1734.

Riser, B. L., Najmabadi, F., Perbal, B., Rambow, J. A., Riser, M. L., Sukowski, E., et al. (2010). $\mathrm{CCN} 3 / \mathrm{CCN} 2$ regulation and the fibrosis of diabetic renal disease. J Cell Commun Signal, 4(1), 39-50.

Rosenblatt, S., Bassuk, J. A., Alpers, C. E., Sage, E. H., Timpl, R., \& Preissner, K. T. (1997). Differential modulation of cell adhesion by interaction between adhesive and counter-adhesive proteins: characterization of the binding of vitronectin to osteonectin (BM40, SPARC). Biochem J, 324 ( Pt 1), 311-319.

Ruegg, C. R., Chiquet-Ehrismann, R., \& Alkan, S. S. (1989). Tenascin, an extracellular matrix protein, exerts immunomodulatory activities. Proc Natl Acad Sci U S A, 86(19), 74377441.

Sage, H., Vernon, R. B., Decker, J., Funk, S., \& Iruela-Arispe, M. L. (1989). Distribution of the calcium-binding protein SPARC in tissues of embryonic and adult mice. J Histochem Cytochem, 37(6), 819-829.

Sato, I., \& Shimada, K. (2001). Quantitative analysis of tenascin in chordae tendineae of human left ventricular papillary muscle with aging. Ann Anat, 183(5), 443-448.

Sawada, Y., Onoda, K., Imanaka-Yoshida, K., Maruyama, J., Yamamoto, K., Yoshida, T., et al. (2007). Tenascin-C synthesized in both donor grafts and recipients accelerates artery graft stenosis. Cardiovasc Res, 74(3), 366-376.

Scatena, M., Liaw, L., \& Giachelli, C. M. (2007). Osteopontin: a multifunctional molecule regulating chronic inflammation and vascular disease. Arterioscler Thromb Vasc Biol, 27(11), 2302-2309. 
Schellings, M. W., Pinto, Y. M., \& Heymans, S. (2004). Matricellular proteins in the heart: possible role during stress and remodeling. Cardiovasc Res, 64(1), 24-31.

Schellings, M. W., Vanhoutte, D., Swinnen, M., Cleutjens, J. P., Debets, J., van Leeuwen, R. E., et al. (2009). Absence of SPARC results in increased cardiac rupture and dysfunction after acute myocardial infarction. J Exp Med, 206(1), 113-123.

Schiemann, B. J., Neil, J. R., \& Schiemann, W. P. (2003). SPARC inhibits epithelial cell proliferation in part through stimulation of the transforming growth factor-betasignaling system. Mol Biol Cell, 14(10), 3977-3988.

Schroen, B., Heymans, S., Sharma, U., Blankesteijn, W. M., Pokharel, S., Cleutjens, J. P., et al. (2004). Thrombospondin-2 is essential for myocardial matrix integrity: increased expression identifies failure-prone cardiac hypertrophy. Circ Res, 95(5), 515-522.

Schultz, G. S., \& Wysocki, A. (2009). Interactions between extracellular matrix and growth factors in wound healing. Wound Repair Regen, 17(2), 153-162.

Serini, G., Bochaton-Piallat, M. L., Ropraz, P., Geinoz, A., Borsi, L., Zardi, L., et al. (1998). The fibronectin domain ED-A is crucial for myofibroblastic phenotype induction by transforming growth factor-beta1. J Cell Biol, 142(3), 873-881.

Shan, J., Huang, Y., Feng, L., Luo, L., Li, C., Ke, N., et al. (2010). A modified technique for heterotopic heart transplantation in rats. J Surg Res, 164(1), 155-161.

Shimazaki, M., Nakamura, K., Kii, I., Kashima, T., Amizuka, N., Li, M., et al. (2008). Periostin is essential for cardiac healing after acute myocardial infarction. $J$ Exp Med, 205(2), 295-303.

Shinohara, M. L., Jansson, M., Hwang, E. S., Werneck, M. B., Glimcher, L. H., \& Cantor, H. (2005). T-bet-dependent expression of osteopontin contributes to T cell polarization. Proc Natl Acad Sci U S A, 102(47), 17101-17106.

Sidhu, S. S., Yuan, S., Innes, A. L., Kerr, S., Woodruff, P. G., Hou, L., et al. (2010). Roles of epithelial cell-derived periostin in TGF-beta activation, collagen production, and collagen gel elasticity in asthma. Proc Natl Acad Sci U S A, 107(32), 14170-14175.

Strandjord, T. P., Madtes, D. K., Weiss, D. J., \& Sage, E. H. (1999). Collagen accumulation is decreased in SPARC-null mice with bleomycin-induced pulmonary fibrosis. Am J Physiol, 277(3 Pt 1), L628-635.

Sun, Y., \& Weber, K. T. (2005). Animal models of cardiac fibrosis. Methods Mol Med, 117, 273290.

Takayama, G., Arima, K., Kanaji, T., Toda, S., Tanaka, H., Shoji, S., et al. (2006). Periostin: a novel component of subepithelial fibrosis of bronchial asthma downstream of IL-4 and IL-13 signals. J Allergy Clin Immunol, 118(1), 98-104.

Tamaoki, M., Imanaka-Yoshida, K., Yokoyama, K., Nishioka, T., Inada, H., Hiroe, M., et al. (2005). Tenascin-C regulates recruitment of myofibroblasts during tissue repair after myocardial injury. Am J Pathol, 167(1), 71-80.

Tamura, A., Shingai, M., Aso, N., Hazuku, T., \& Nasu, M. (2003). Osteopontin is released from the heart into the coronary circulation in patients with a previous anterior wall myocardial infarction. Circ J, 67(9), 742-744.

Trueblood, N. A., Xie, Z., Communal, C., Sam, F., Ngoy, S., Liaw, L., et al. (2001). Exaggerated left ventricular dilation and reduced collagen deposition after myocardial infarction in mice lacking osteopontin. Circ Res, 88(10), 1080-1087.

Uzel, M. I., Scott, I. C., Babakhanlou-Chase, H., Palamakumbura, A. H., Pappano, W. N., Hong, H. H., et al. (2001). Multiple bone morphogenetic protein 1-related 
mammalian metalloproteinases process pro-lysyl oxidase at the correct physiological site and control lysyl oxidase activation in mouse embryo fibroblast cultures. J Biol Chem, 276(25), 22537-22543.

Waller, A. H., Sanchez-Ross, M., Kaluski, E., \& Klapholz, M. (2010). Osteopontin in cardiovascular disease: a potential therapeutic target. Cardiol Rev, 18(3), 125-131.

Wang, J. C., Lai, S., Guo, X., Zhang, X., de Crombrugghe, B., Sonnylal, S., et al. (2010). Attenuation of fibrosis in vitro and in vivo with SPARC siRNA. Arthritis Res Ther, 12(2), R60.

Weber, G. F., Zawaideh, S., Hikita, S., Kumar, V. A., Cantor, H., \& Ashkar, S. (2002). Phosphorylation-dependent interaction of osteopontin with its receptors regulates macrophage migration and activation. J Leukoc Biol, 72(4), 752-761.

Weiss, J. M., Renkl, A. C., Maier, C. S., Kimmig, M., Liaw, L., Ahrens, T., et al. (2001). Osteopontin is involved in the initiation of cutaneous contact hypersensitivity by inducing Langerhans and dendritic cell migration to lymph nodes. J Exp Med, 194(9), 1219-1229.

Winters, G. L. \& Schoen, F. J. (2001). Pathology of cardiac transplantation. In M. D. Silver, G. A. I. \& F. J. Schoen (Eds.), Cardiovascular Pathology (pp. 725-762): Churchill Livingstone.

Wipff, P. J., \& Hinz, B. (2009). Myofibroblasts work best under stress. J Bodyw Mov Ther, 13(2), 121-127.

Wynn, T. A. (2008). Cellular and molecular mechanisms of fibrosis. J Pathol, 214(2), 199-210.

Xie, X. S., Li, F. Y., Liu, H. C., Deng, Y., Li, Z., \& Fan, J. M. (2010). LSKL, a peptide antagonist of thrombospondin-1, attenuates renal interstitial fibrosis in rats with unilateral ureteral obstruction. Arch Pharm Res, 33(2), 275-284.

Yumoto, K., Ishijima, M., Rittling, S. R., Tsuji, K., Tsuchiya, Y., Kon, S., et al. (2002). Osteopontin deficiency protects joints against destruction in anti-type II collagen antibody-induced arthritis in mice. Proc Natl Acad Sci U S A, 99(7), 4556-4561.

Zhao, X. M., Hu, Y., Miller, G. G., Mitchell, R. N., \& Libby, P. (2001). Association of thrombospondin-1 and cardiac allograft vasculopathy in human cardiac allografts. Circulation, 103(4), 525-531.

Zhou, Y., Poczatek, M. H., Berecek, K. H., \& Murphy-Ullrich, J. E. (2006). Thrombospondin 1 mediates angiotensin II induction of TGF-beta activation by cardiac and renal cells under both high and low glucose conditions. Biochem Biophys Res Commun, 339(2), 633-641. 


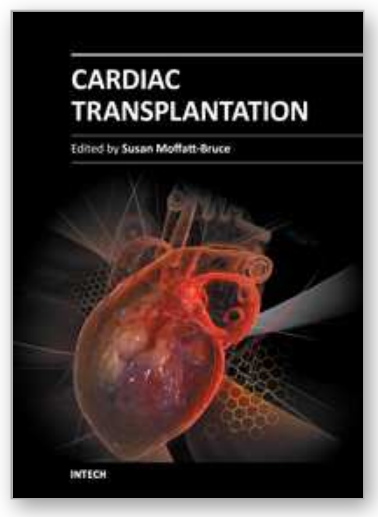

\author{
Cardiac Transplantation \\ Edited by Dr. Susan Moffatt-Bruce
}

ISBN 978-953-51-0000-3

Hard cover, 154 pages

Publisher InTech

Published online 10, February, 2012

Published in print edition February, 2012

We are truly in an era of change not only in terms of technology but in the type of patient we are caring for. That is why I feel this book is exciting in that it presents the team approach to the transplant patient. I am confident that the pioneers of cardiac transplantation would be pleased with our response to challenges in healthcare today and be pleased with the final product.

\title{
How to reference
}

In order to correctly reference this scholarly work, feel free to copy and paste the following:

Nadine Frerker, Monika Kasprzycka, Bjørg Mikalsen, Pål Dag Line, Helge Scott and Guttorm Haraldsen (2012). Role of Matricellular Proteins in Cardiac Allograft Fibrosis, Cardiac Transplantation, Dr. Susan MoffattBruce (Ed.), ISBN: 978-953-51-0000-3, InTech, Available from: http://www.intechopen.com/books/cardiactransplantation/transplant-vasculopathy-and-development-of-graft-sclerosis-fibrosis

\section{INTECH}

open science | open minds

\author{
InTech Europe \\ University Campus STeP Ri \\ Slavka Krautzeka 83/A \\ 51000 Rijeka, Croatia \\ Phone: +385 (51) 770447 \\ Fax: +385 (51) 686166 \\ www.intechopen.com
}

\author{
InTech China \\ Unit 405, Office Block, Hotel Equatorial Shanghai \\ No.65, Yan An Road (West), Shanghai, 200040, China \\ 中国上海市延安西路 65 号上海国际贵都大饭店办公楼 405 单元 \\ Phone: +86-21-62489820 \\ Fax: $+86-21-62489821$
}


(C) 2012 The Author(s). Licensee IntechOpen. This is an open access article distributed under the terms of the Creative Commons Attribution 3.0 License, which permits unrestricted use, distribution, and reproduction in any medium, provided the original work is properly cited. 